Discussion Paper No. 08-133

Employment Adjustments on the Internal and External Labour Market An Empirical Study with Personnel Records of a German Company

Knut Gerlach and Olaf Hübler

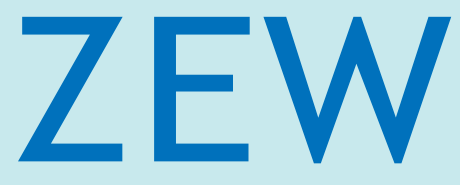

Zentrum für Europäische Wirtschaftsforschung $\mathrm{GmbH}$

Centre for European

Economic Research 
Discussion Paper No. 08-133

\title{
Employment Adjustments on the Internal and External Labour Market - An Empirical Study with Personnel Records of a German Company
}

\author{
Knut Gerlach and Olaf Hübler
}

Download this ZEW Discussion Paper from our ftp server:

ftp://ftp.zew.de/pub/zew-docs/dp/dp08133.pdf

Die Discussion Papers dienen einer möglichst schnellen Verbreitung von neueren Forschungsarbeiten des ZEW. Die Beiträge liegen in alleiniger Verantwortung der Autoren und stellen nicht notwendigerweise die Meinung des ZEW dar.

Discussion Papers are intended to make results of ZEW research promptly available to other economists in order to encourage discussion and suggestions for revisions. The authors are solely responsible for the contents which do not necessarily represent the opinion of the ZEW. 


\section{Das Wichtigste in Kürze}

Unternehmen sind Nachfrageänderungen ausgesetzt. Daraus resultieren Beschäftigungsanpassungen. Diese können innerhalb des Unternehmens erfolgen. Zwei prominente Möglichkeiten stellen die Ausweitung oder Reduktion der Arbeitszeit, insbesondere der Überstunden und eine Modifikation im Beförderungsverhalten dar. Neben diesen Anpassungen auf dem internen Arbeitsmarkt lassen sich vor allem Veränderungen bei der Beschäftigtenzahl vornehmen. Hiervon ist der externe Arbeitsmarkt betroffen. Zwei bisher empirisch kaum untersuchte Fragen sind, ob es einerseits einen Zusammenhang zwischen den Instrumenten der internen Anpassung gibt und welche Verbindungen andererseits zu den externen Anpassungen bestehen, ob die Prozesse komplementär oder substitutiv verlaufen. Zudem ist von Bedeutung herauszufinden, ob sich im Zeitablauf eine klare Tendenz herauskristallisieren lässt und wie die Anpassungen im Zyklus verlaufen. Anliegen des Beitrages ist, diesen Fragen empirisch nachzugehen.

Für die Studie steht ein umfangreicher Datensatz eines großen deutschen Unternehmens des Verarbeitenden Gewerbes, das innovative Produkte auf dem heimischen und ausländischen Markt anbietet, für den Zeitraum 1999 bis 2005 zur Verfügung. Auch wenn wegen des Einzelfallcharakters Verallgemeinerungen der Ergebnisse nur sehr beschränkt möglich sind, weisen die verfügbaren Informationen, die direkt aus den Unternehmensunterlagen entstammen, verschiedene Vorteile gegenüber anderen Datensätzen auf. Erstens ist der Verlässlichkeitsgrad der Daten sehr hoch. Zweitens bestehen keine Probleme hinsichtlich unbeobachteter Heterogenität, soweit es Unternehmens-, Wirtschaftsbereich- und Regionalmerkmale betrifft. Drittens liegen detaillierte Angaben über die Art der Beschäftigungsanpassung sowie über monetäre Anreizinstrumente vor. Und viertens sind die Angaben monatlich.

Die empirische Analyse liefert zunächst deskriptive Ergebnisse. Daraus wird deutlich, dass der Beschäftigungszyklus des Unternehmens zwar weitgehend, aber nicht vollständig mit den volkswirtschaftlichen Bewegungen übereinstimmt, dass interne und externe Anpassungen eher komplementär als substitutiv verlaufen, dass sich kaum analoge Lohnanpassungen ausmachen lassen, dass von 2002 auf 2003 ein deutlicher Einschnitt bei der Beschäftigtenzahl eingetreten ist. Die ökonometrische Untersuchung stützt sich auf einen zweistufigen Ansatz, bei dem zunächst mit Hilfe eines bivariaten Probitmodells der Zusammenhang zwischen Überstunden und Beförderung herausgearbeitet wird. Hierbei zeigt sich - nicht unbedingt erwartet -, dass unbeobachtete Determinanten diese beiden Anpassungsinstrumente in entgegen gesetzter Richtung beeinflussen, dass eine abnehmende Tendenz interner Beschäftigungsänderungen besteht und sich keine ausgeprägten zyklischen Effekte ausmachen lassen. Die sich anschließende Bestimmung des Einflusses von Überstunden- und Beförderungsänderungen auf die Beschäftigtenzahl erfolgt einerseits unabhängig von der Art der Anpassung. Andererseits wird zwischen Kündigungen, Entlassungen, Auflösungsverträgen und Wechsel in eine Transfergesellschaft unterschieden. Im ersteren Fall zeigt sich, dass Beförderungen die Mobilitätsneigung reduzieren, während Überstunden das Gegenteil bewirken. Dieses Grundmuster bleibt im Wesentlichen bestehen, wenn nach der Art der Beschäftigungstrennung differenziert wird. Nur bei den Kündigungen ergeben sich die umgekehrten Effekte und bei den Auflösungsverträgen lassen sich keine Wirkungen von Beförderungen aufdecken. 


\section{Non-Technical Summary}

Firms are affected by the product demand. This leads to employment adjustments. On the internal labour market there exist two prominent possibilities, changes of working hours, especially overtime, and modifications of promotion measures. On the external labour market the number of employees can be adjusted. In the literature we find only very few contributions investigating the issue whether internal adjustments are linked and which relationships exist with external adjustments. Are they of a complementary or substitutive nature? Furthermore it is of interest to find out, whether we can observe an obvious trend and whether the adjustments are driven by cyclical movements.

For this study we have an extensive data set of a large German manufacturing company, which supplies innovative products for the domestic and international market, provided on a monthly base from January 1999 to December 2005. Although this type of data allows only restricted generalisations of the results, the available information has several advantages compared with other data sets: (1) The data are very reliable because they are directly extracted from the human resources management of the company; (2) there do not exist problems with unobserved heterogeneity due to firms, branch or regional characteristics; (3) they allow to distinguish between several types of external employment adjustment and we can use information on monetary incentive instruments; (4) monthly, not only yearly data are provided.

The empirical analysis starts with descriptive statistics. We find that the employment adjustment cycle coincides only to a certain degree with the macroeconomic cycle. Internal and external adjustments are more characterized by complementarity than by substitution. Over the observed period we cannot detect analogous wage adjustments. It is noticeable that in 2003 compared with the years before the number of employees is substantially reduced. The econometric investigation is based on a two-stage approach. We start with a bivariate probit estimation in order to extract the relationship between the probability of overtime and of promotion. Unobserved variables have opposite effects on the former and the latter adjustment instrument. Furthermore, we detect a negative trend of internal employment adjustments. Cyclical effects are ambiguous. The next step, the determination of external adjustments with respect to overtime and promotion adjustments, is split into two estimates. On the one hand we do not distinguish between the type of external employment adjustment and on the other hand we use this information separating between quits, layoffs, workers with a cancellation agreement and with a transition into a transfer organisation. The first appoach demonstrates that a promotion reduces the probability to leave the firm while overtime is positively associated with an external job change. This pattern holds generally speaking in the second, more detailed estimates. Quits are the exception. In this case we observe opposite effects. Finally, we cannot detect any influences of promotions on cancellation agreements. 


\title{
Employment Adjustments on the Internal and External Labour Market - an Empirical Study with Personnel Records of a German Company ${ }^{+}$
}

\author{
Knut Gerlach* and Olaf Hübler**
}

\begin{abstract}
:
Firms are affected by the product demand. This leads to employment adjustments. In the literature we find only very few contributions investigating the issue whether internal adjustments are linked and which relationships exist with external adjustments. Are they of a complementary or substitutive nature? Furthermore, it is of interest to find out, whether we can observe an obvious trend and whether the adjustments are driven by cyclical movements.

For this study we have an extensive data set of a large German manufacturing company, which supplies innovative products for the domestic and international market, provided on a monthly base from January 1999 to December 2005. The empirical analysis starts with descriptive statistics. We find that the employment adjustment cycle coincides only to a certain degree with the macroeconomic cycle. Internal and external adjustments are more characterized by complementarity than by substitution. Over the observed period we cannot detect analogous wage adjustments. It is noticeable that in 2003 compared with the years before the number of employees is substantially reduced. The econometric investigation is based on a two-stage approach. We start with a bivariate probit estimation in order to extract the relationship between the probability of overtime and of promotion. Unobserved variables have opposite effects on the former and the latter adjustment instrument. Furthermore, we detect a negative trend of internal employment adjustments. Cyclical effects are ambiguous. The next step, the determination of external adjustments with respect to overtime and promotion adjustments, is split into two estimates. On the one hand we do not distinguish between the type of external employment adjustment and on the other hand we use this information separating between quits, layoffs, workers with a cancellation agreement and with a transition into a transfer organisation. The first approach demonstrates that a promotion reduces the probability to leave the firm while overtime is positively associated with an external job change. This pattern holds generally speaking in the second, more detailed estimates. Quits are the exception. In this case we observe opposite effects. Finally, we cannot detect any influences of promotions on cancellation agreements.
\end{abstract}

Keywords: Personnel records, overtime, promotion, job mobility, cancellation agreement, transfer organisation

JEL classification: J63, M51

\footnotetext{
${ }^{+}$We thank Thomas Cornelißen, Bernd Fitzenberger, Christian Pfeifer and a referee for helpful comments.

* Leibniz University Hannover, Institute of Labour Economics, Königsworther Platz 1,D-30167 Hannover, e-mail: gerlach@aoek.uni-hannover.de

** Leibniz University Hannover, Institute of Empirical Economics, Königsworther Platz 1, D-30167 Hannover, e-mail: huebler@ewifo.uni-hannover.de
} 


\section{Introduction}

This study contributes to the growing literature on internal labour markets that is based on personnel records (Baker/Holmstrom 1995, Grund 2002, Lin 2005, Pfeifer 2008). This literature, which is summarized by Lin (2005), shows that the internal and external labour markets communicate at all hierarchical levels, hence there is not much evidence of ports of exit and entry. Further it demonstrates that stable hierarchies with career ladder exist and promotions are significant for wage growth. In addition, wage variations are large within job levels and the internal labour markets are to a certain extent shielded from external market forces in the sense that market forces exert an impact on wages at the time of entry (cohort effects), but this effect is much weaker inside the company.

The relationship between internal labour market flexibility and the types as well as the degree of external adjustments, however, has received less attention in the literature. It is this imbalance that we want to redress. In a first step, we examine the individual or company induced determinants of internal flexibility such as promotions and overtime work and the extent to which they are positively or negatively interrelated. Secondly, we address the issue whether and to which extent internal flexibility exerts an impact on external adjustments. Are internal and external mobility substitutes or complements? Thirdly, we distinguish between various types of external mobility, namely quits, dismissals, cancellation agreements and transitions to a transfer organisation and examine whether differences in the relationship between internal adjustments and the types of external mobility can be detected. Finally, we investigate the impact of cyclical effects on internal and external mobility during the period covered by our data (1999-2005).

The paper is organised as follows. Section 2 discusses briefly the theoretical background and the related literature. In Section 3 the company and the data are described and the advantages and shortcomings of using data from personnel records are discussed. Section 4 presents descriptive statistics and Section 5 contains the methods and results of the econometric investigation. Section 6 summarizes the basic results.

\section{Background and related literature}

The traditional market coordination which implies that quantities adapt to price changes and vice versa is only in part applicable to basic dimensions of external labour markets such as employment and wages. Nominal wages tend to be rigid downwards which leads to real wage rigidity at low inflation rates (Franz/Pfeiffer 2003, Knoppik/Beissinger 2003, Cornelißen/Hübler 2008). Wage rigidities can increase workers' utility by insuring them against income losses and might keep companies profitable if alternative measures of adjustment such as layoffs are less costly.

Wage rigidities in conjunction with a substantial level of employment stability and opportunities for occupational careers constitute significant elements of internal labour markets which shield incumbents from negative shocks in external labour markets. For internal labour markets administrative rules and procedures as well as custom are important ingredients (Doeringer/Piore 1971, Schlicht 1998) 
and these markets interact with external labour markets through specific ports of entry and exit. The observations of Doeringer and Piore (1971) inspired a broad scope of economic theories to explain the functioning of internal labour markets ranging from specific human capital, principal-agent, learning and matching theories to tournament theories (see Cahuc/Zylberberg 2001, chapter 6 for an excellent summary). All in all, until recently internal labour markets were interpreted as entities which strengthen and intensify the adjustment deficits of external labour markets. This conventional perspective, however, was challenged by Gibbs and Hendricks (2004). The authors show with the personnel records of a large U.S. corporation that a strictly administered salary system is capable to mirror the wage fluctuations emanating from the external labour market and at the same time the corporation can retain the efficiency enhancing ingredients (like reduction of transaction costs, stimulation of motivation, lowering of turnover and facilitating the accumulation of specific human capital) on its internal labour market.

Generally, there is a broad consensus that especially firms with internal labour markets prefer layoffs to wage cuts in periods of a slack demand (Bewley 2005). Layoffs are less detrimental than pay cuts to employees' morale, layoffs affect morale only temporarily, whereas the damage to morale of pay cuts endures. Layoffs tend to enhance productivity which is negatively affected by wage reductions. To some extent management can control which workers are laid off, thus avoiding that employees which the firm wants to retain leave when wages are reduced. In addition, layoffs diminish the substantial fixed costs of employment, whereas pay cuts save only the variable portion of compensation.

Firms with internal labour markets offering employment stability, however, also have to react to negative demand shocks. They can try to honour their employment commitment by internal adjustments. Variations of working times such as reduced overtime, extended part-time work and delayed promotions are measures to stabilize employment and to cut wage costs. In addition, contingent labour can be employed which is easy to dismiss in periods of slack demand. As an alternative firms can adjust to negative demand shocks by dismissing workers.

The amount of research relating internal labour market mobility to external employment adjustments is very limited (Cappelli/Neumark 2004). The fundamental issue is whether the kind of flexibility such as employment stability in conjunction with promotions, overtime, further training, team work and work reorganisation that can be attained through internal labour markets is a substitute or a complement to external labour market flexibility. On the one hand, with a given level of employment stability policies and practices which strengthen the internal market, for example, by variations of overtime work and adapting promotions to cyclical conditions as well as by training employees for new tasks might covary with a smaller amount of external labour adjustments. On the other hand, companies confronted with the need of strong and frequent employment adjustments may implement policies and practices that combine internal and external flexibility. "Simple arguments about diminishing returns suggest that it may be more effective to put one's efforts into multiple mechanisms to achieve a given result than into only one" (Cappeli/Neumark 2004: 153). Interestingly, the authors find that in manufacturing substitution prevails, i.e. team-work and various measures of work restructuring are negatively correlated with involuntary 
and voluntary turnover. Non-manufacturing, however, is characterised by a complementarity of internal and external flexibility. This result is basically attributed to the impediment of keeping inventories and to the stronger variations in peak demand requiring adjustments in the pace and quantity of work in the service sector.

Turning now to the institutional conditions in Germany we distinguish between two cases: Layoffs that take into account the dismissal protection law (Kündigungsschutzgesetz) and layoffs in conjunction with cost reduction that are in addition based on a consensus between the incumbents and management. In the second case either a company-level pact for employment is negotiated or a transfer organisation (Transfergesellschaft) is established. In both cases the company's works council is involved, albeit its participation is stronger in the second case as the works council acts as a partner of management in elaborating and implementing the consensus.

In the first case the firm has to adhere to the social selection criteria stipulated by the dismissal protection law. These comprise tenure, age, obligations to pay alimony and the status of severe disablement. However, incumbents whose employment is of vital importance for the firm are exempt from these criteria. Further the law requires redundancy payments, i.e. 50 percent of the monthly income for each year of tenure. Frequently, works councils negotiate more generous severance payments. In addition, workers who consider quitting because they plan to retire or to search a new job can negotiate lucrative cancellation agreements (Auflösungsverträge) of their employment contracts. This type of separation verges on normal quits which, however, are less frequent in periods of slack demand. All in all, these employment protection measures pursue the goals to preserve employment by increasing the cost of layoffs and reducing risks of employment and pay to wage-earners. The measures might attain these goals, although at the cost of a lower rate of job creation and by concentrating the burden of employment and wage risks on selected groups such as long-term unemployed as well as younger and older people (Cahuc/Zylberberg 2006).

As previously mentioned layoffs implemented with the aim of cost reduction can be based on company-level pacts for employment or transfer organisations. They usually require an agreement between management and the works council. Firms tend to use company-level pacts if the aim of cost reduction cannot be achieved by individual dismissals because they are too expensive. The pacts encompass concessions by management and the workforce and they specify deviations from the collective agreement (Tarifvertrag) (Hübler 2005, 2006). A consensus between the respective union and employers' association is normally requested.

A transfer organisation is established as an operational entity in its own right (eigenständige betriebsorganisatorische Einheit). Instead of a dismissal employees conclude a fixed-term employment contract with the transfer organisation and are thus no longer employed by the original firm. The operational entity provides counselling, supports job search activities and offers further training for new jobs and careers. In addition, the inception of unemployment is delayed while being employed by the transfer organisation and the probability of finding a job might increase. The benefits for a firm decreasing its level of employment comprise planning reliability and legal certainty as the workers switching to the transfer 
organisation can no longer take legal action against a discharge (Paprotny 2008). Additionally, the firm is not restricted by statutory periods of notice and disposes of more leeway for selecting the employees it wants to discharge than in the cases of layoffs or cancellation agreements. These benefits, however, are costly. Although the Federal Labour Agency pays short-term working allowances to employees of the transfer organisation (Transferkurzarbeitergeld) the firm reducing employment usually has to supplement these payments and to incur the costs of qualification and counselling. Given the conditions of employment protection in Germany implementing layoffs by establishing transfer organisations appears to be in terms of Bewley (2005: 310) a good management practice: " to delay potential layoffs until the employer can make a large number all at once, and then to assure those who remain that there will be no more layoffs for some time".

\section{Data}

The data for this analysis were provided by a large German manufacturing company, which supplies innovative products for the domestic and international market. Several interviews with high-ranking employees of the company's personnel administration were helpful for interpreting the data and clarifying institutional details. The company, which employs on average about 1500 men and women in the period investigated, has a works council and applies an industry-wide collective agreement. The data were directly extracted from the personnel records of the company's computer system and provided on a monthly basis from January 1999 to December 2005. Our empirical analysis excludes apprentices and trainees.

Using the personnel records of a company for the study of employment adjustments entails advantages and some shortcomings. First, the information is more reliable than data based on voluntary surveys and even most official statistical information as they are directly extracted from the human resources management of a company (Grund 2002). Second, it is relatively homogeneous with respect to the workforce as it covers only one company in a specific sector and region. Third, the data set at our disposal provides information on alternative measures to adjust employment such as promotions, overtime work, cancellation agreements and transitions into a transfer organisation which are usually not available in a differentiated form. Fourth, the data set allows to distinguish between various monetary measures like monthly gross wages, grants and variability of compensation which might be implemented to accompany employment adjustments. Finally and importantly, the data contain information about exits or separations on a monthly basis.

Concerning the shortcomings it is evident that an investigation with this type of data amounts to a case study with restricted opportunities to generalize. Comparisons with other companies, sectors or manufacturing industry are not feasible. Specifically, our data set is limited in the sense that information about further training, reorganisation of work and team work are not available. 


\section{Descriptive statistics}

As previously mentioned, the personnel data of the firm are available on a monthly base. A short description of the applied variables, means, standard deviations and number of employee-months are presented in Table 1. The total number of observations (employee-months) is $\mathrm{N}=123$ 896. If the workforce in the firm had remained the same as in January $1999\left(\mathrm{n} \_1 / 1999=1290\right)$ in the entire period we would have 7 years x 12 months x 1290=108360 observations. This means compared with the actual number of observations or with the number of workers in December 2005 (n_12/2005=1402) that the firm expanded, but this development was not continuous. The last row of Table 2a shows the number of employees in the last month of the year. In 2002 the maximum is reached $\left(\mathrm{n} \_12 / 2002=1599\right)$.

We investigate employment adjustments by three indicators, namely by two dummy variables which describe the employment changes on the internal labour market (promotion - PROM, overtime work - OT) and one dummy variable (external job mobility - EJM) which demonstrates separations from the firm to the external labour market. Roughly $0.4 \%$ of the workforce left the firm per month within the period 1999-2005, while $0.5 \%$ was promoted and $8.5 \%$ worked overtime - see Table 1. Hence we observe internal as well as external mobility. However, at this stage we are not able to say anything about the relationship between these movements and about the determinants of job mobility. Furthermore, the dynamics of the variables are of interest.

In Table 2a-2b the development of the relevant mobility variables is exhibited for the period 1999 to 2005. (For a detailed descriptive investigation of entries and exits by hierarchical levels see Gerlach/Pfeifer 2006.) All in all, the numbers show that the firm is characterized by two phases. First, from 1999 to 2002 employment expands as indicated by the December figures. Subsequently, the number of employees decreases again, but the final level is higher than the starting value. Less workers leave the firm and more enter from 1999 to 2002 than in the subsequent years. Nevertheless tenure does not change systematically. In 2003 and 2005 we observe a difficult economic situation in the firm. This contrasts partially with the business cycle in Germany with the highest unemployment rate in 1999 and 2005, but not in 2003. Overtime working and promotions are less frequent in 2003 to 2005 than in the previous years. Apparently, internal and external labour mobility move in parallel. However, the standard working hours per month tend to decline from 1999 to 2003 and subsequently a minor rise can be observed (not in the Tables). This development is not accompanied by reduced wages (WAGE) and falling supplementary grants (GRANTS) on average. Only in 2002 the average wage declines. The ratio of workers exposed to a negative wage growth (0.9-6.9\%) or negative supplementary grant growth (1.4-4.6\%) remains very low and does not follow a positive trend (not in the Tables). Hence there is evidence of wage rigidity.

The figures in Table $2 \mathrm{a}$ and $2 \mathrm{~b}$ are not completely comparable. In Table $2 \mathrm{a}$ the number of workers is based on the last month of the year. In Table $2 b$ the total number of mobility cases per year is displayed but the reason for separation is not available for all workers who leave the firm. The strongest restructuring of the firm is observed in 2003 and 2005. Insofar our firm follows the general 
phenomenon that enterprises concentrate their adjustments on few and limited periods. The difference between 2003 and 2005 is that in the former year the transfer organisation is intensively used for reducing employment, whereas the latter year is characterised by internal job changes. A first step in downsizing is followed by the reorganisation of the firm. Noteworthy is the low number of dismissals during the entire period (see Table $2 b$ ).

Table 2c presents some detailed information for the critical year 2003. It is evident that external job mobility (EJM) and overtime working (OT) are not very different comparing younger and older employees, whereas the probability of promotion is higher for younger workers and, of course, older employees have a longer tenure. If we compare men and women the most striking result is the male dominance in overtime working. It is noteworthy that workers with a longer education have a higher probability to quit and as a consequence a shorter tenure than employees with less education. The latter are more involved in overtime work.

\section{Econometric investigations}

\subsection{Methods}

In the following our econometric results are presented. On the one hand the effects of individual characteristics and macroeconomic variables $\left(\mathrm{x}_{1}\right)$ on the internal mobility are determined. On the other hand external mobility, expressed by a dummy whether an individual has left the firm (EJM - $\left.\mathrm{y}_{3}\right)$, is estimated. We expect that promotion (PROM $\left.-\mathrm{y}_{1}\right)$ and overtime working $\left(\mathrm{OT}-\mathrm{y}_{2}\right)$ are related to jointly unobserved influences. As these variables are measured by dummies we assume a bivariate probit model

$$
\begin{aligned}
& \mathrm{y}_{1}{ }^{*}=\mathrm{x}_{1}{ }^{\prime} \beta_{1}+\mathrm{u}_{1} \\
& \mathrm{y}_{2}{ }^{*}=\mathrm{x}_{1}{ }^{\prime} \beta_{2}+\mathrm{u}_{2} \\
& \mathrm{E}\left(\mathrm{u}_{1}\right)=\mathrm{E}\left(\mathrm{u}_{2}\right)=0 \\
& \mathrm{~V}\left(\mathrm{u}_{1}\right)=\mathrm{V}\left(\mathrm{u}_{2}\right)=1 \\
& \operatorname{Cov}\left(\mathrm{u}_{1}, \mathrm{u}_{2}\right)=\rho,
\end{aligned}
$$

where $\mathrm{y}_{1} *$ and $\mathrm{y}_{2} *$ are latent variables. We observe only $\mathrm{y}_{\mathrm{k}}=1$ if $\mathrm{y}_{\mathrm{k}} *>0$ and $\mathrm{y}_{\mathrm{k}}=0$ if $\mathrm{y}_{\mathrm{k}} *<=0$ for $\mathrm{k}=1 ; 2$. The coefficients are estimated by the ML method where the covariance matrix is determined with a cluster robust procedure as employeemonths are considered which are correlated within the group of an individual. The likelihood function is specified by

$$
\begin{aligned}
& \ln \mathrm{L}=\sum_{i=1}^{n} \ln \Phi\left(q_{1 i} x_{1 i}{ }^{\prime} \beta_{1}, q_{2 i} x_{1 i}{ }^{\prime} \beta_{2}, \rho_{i}{ }^{*}\right) \\
& q_{k i}=+1 \text { if } y_{k i} \neq 0 ; \mathrm{q}_{k i}=-1 \text { otherwise where } \mathrm{k}=1 ; 2 . \\
& \rho_{i}^{*}=q_{1 i} q_{2 i} \rho .
\end{aligned}
$$

In vector $\mathrm{x}_{1}$ the following variables are incorporated: GRANTS, VCOMP, TARGET, WAGE, WAGE ${ }^{2}$, AGE, AGE ${ }^{2}$, SCHOOL, WC, TRAIN, WHOURS, UR, YEAR (see Table 1). 
The next step is to estimate external job mobility (EJM - $\mathrm{y}_{3}$ ). Again a probit model is used and the covariance matrix is determined with a cluster robust procedure. As robustness check the random effects panel estimator is added. As we want to analyse whether internal mobility has an impact on EJM we incorporate the internal mobility variables and control for macroeconomic variables and individual characteristics $\left(\mathrm{x}_{3}\right)$. Interdependencies are likely. Therefore, PROM and OT are substituted by the estimates of $\mathrm{y}_{1} *$ and $\mathrm{y}_{2} *$ ( $\hat{y}_{1}=e P R O M, \hat{y}_{2}=e O T$ ) following Olsen (1980) and Newey (1999) extended to the bivariate probit case

$$
y_{3}{ }^{*}=\hat{y}_{1} \alpha_{1}+\hat{y}_{2} \alpha_{2}+x_{3}{ }^{\prime} \beta_{3}+u_{3} \text {. }
$$

The vector $x_{3}$ contains the variables: GRANTS, VCOMP, WAGE, TEN9905, WHOURS, SCHOOL, SEX, KIDS, UR and YEAR (see Table 1). Finally, the EJM variable is split in accordance with the reason to leave the firm (REASON). Four reasons are distinguished, namely quits $\left(\mathrm{y}_{31}\right)$, layoffs $\left(\mathrm{y}_{32}\right)$, cancellation agreements $\left(\mathrm{y}_{33}\right)$ and entry into a transfer organisation $\left(\mathrm{y}_{34}\right)$. Subsequently, a multinomial probit model is estimated by the Gaussian quadrature procedure. The multidimensional integral is reduced to one dimension. Workers with other reasons of job changes (end of fixed-term contract, dismissal without notice, internal job change, retirement, death) are not considered in the multinomial probit estimation. The probability that individual $\mathrm{i}$ choose alternative $\mathrm{k}$ is

$$
\mathrm{P}\left(v_{\mathrm{i} 1 \mathrm{j}}<=0, \ldots, v_{\mathrm{i}, \mathrm{J}-1, \mathrm{j}}<=0\right),
$$

where the alternatives (reasons to leave the firm) are $1,2, \ldots, \mathrm{j}, \ldots \mathrm{J}$ and

$v_{i j j^{\prime}}=\eta_{i j}-\eta_{i j^{\prime}}=x_{3 i}{ }^{\prime}\left(\gamma_{j}-\gamma_{j^{\prime}}\right)+\left(\varepsilon_{i j}-\varepsilon_{i j^{\prime}}\right)=: x_{3 i}{ }^{\prime} \gamma_{j j^{\prime}}+\varepsilon_{i j j^{\prime}}$,

where the alternatives $\mathrm{j}$ and $\mathrm{j}$ ' are compared. The multinomial logit approach is not used because it is difficult to explain that the internal job mobility is determined by a probit model while the external model is based on a logit model. Furthermore, the Hausman tests reject the necessary IIA condition of the logit model. The $\chi^{2}$ - test statistics of the same specification as in Table 5 demonstrate this for the logit model

$\chi^{2}=64.26(p-$ value $=0.0005)$ if reason 1 is eliminated ;

$\chi^{2}=52.26(p-$ value $=0.0005)$ if reason 2 is eliminated ;

$\chi^{2}=36.69(p-$ value $=0.0470)$ if reason 3 is eliminated ;

$\chi^{2}=214.47(p-$ value $=0.0000)$ if reason 4 is eliminated .

An open question is whether individuals react instantaneously or lagged on internal labour market changes with external adjustments. From our view both possibilities should be considered and therefore we extend the static model by lagged influences.

An alternative to our two-stage approach might be a trivariate probit model where promotion, overtime and separation are jointly related to unobserved individual influences. Though we have checked this idea our investigation concentrates on 
the stepwise procedure. We argue that employees do not decide jointly on internal and external adjustments. The determinants are not identical. Internal adjustments have priority for the workers whereas external mobility is a second order problem. One of our main objectives in this paper is to analyse explicitly the influence of internal on external adjustments. We want to ascertain whether these two types of adjustment are complements or substitutes. A trivariate probit model seems to us less adequate for this issue. Furthermore, it is difficult to incorporate dynamic processes and the various types of external mobility in this model. The application of the trivariate approach has shown that the incorporation of lagged overtime working and promotion effects does not perform well. The estimates which use the GHK simulator cannot evaluate the likelihood function.

\subsection{Results}

The bivariate probit estimates in Table 3 show the relationship between promotion and overtime work, our two indicators of internal mobility. A priori it is ambiguous whether the link is positive or negative. The firm might promote the most productive workers and the employees who are strongly involved in overtime work. However, for our firm we observe the opposite with a negative and significant correlation (rho $=-0.09$ ). The reason might be that the requested abilities for promotion and overtime work differ. The former should encompass characteristics such as decisiveness and tenacity in negotiations, willingness to accept responsibility as well as less risk-aversion. Overtime work, however, is more important for less educated workers. ${ }^{1}$ Due to employment protection firms are reluctant to hire employees if product demand increases temporarily. The alternative is overtime work. The estimates confirm this hypothesis. In the OT function the coefficient of the regressor SCHOOL is negatively significant. The opposite is expected in the PROM equation. However, we find an insignificant influence. Altogether the PROM equation is suboptimal compared with the OT equation. Only few effects are significant. A nonlinear wage influence is detected. Initially, the probability rises with wage and roughly at a monthly wage of $€ 4000$ the probability decreases again. Furthermore, a white collar worker has better chances to be promoted. A striking result is the negative trend in the promotion and in the overtime function. Both indicators of internal mobility are less important in the end than in the beginning of the considered period. Evidently, the relevance of the internal labour market has declined. Cyclical effects expressed by the unemployment rate (UR) cannot be detected. It should be stressed that wage has also a nonlinear influence of second order on OT. This could contradict the hypothesis of especially less educated employees performing

\footnotetext{
${ }^{1}$ We have tested whether the negative correlation between overtime and promotion vanishes when lagged overtime is incorporated. The hypothesis is that a prior commitment to work overtime increases the probability to be promoted. However, the estimates of this approach do not confirm this conjecture, promotion and lagged overtime are negatively correlated in our data set, too - not in the Tables. A further reason of the negative correlation might be a data problem, namely that overtime is not always correctly recorded. With a higher position of an individual within the firm's hierarchy the probability that overtime is unpaid and that these hours are not documented might increase. One can also suppose that overtime for white collar workers who receive a fixed monthly salary is not correctly recorded. And finally, incomplete recording is likely if the firm has introduced a working hours account (Arbeitszeitkonto). We cannot test these suppositions, however, the management of our firm has declared that they have recorded all hours of overtime working because the works council requires this information.
} 
overtime work. However, the coefficients of SCHOOL and TRAIN support our interpretation.

The next step is the analysis of external mobility. We investigate the determinants that an individual separates from the firm (EJM). For this purpose a probit model is estimated. The results are presented in Table 4. We are especially interested in detecting whether internal mobility has an impact on external mobility when interdependencies are taken into account (ePROM, eOT). The result in column (1) and also in column (3) where a random effects panel estimator is applied is obvious: Promoted employees (ePROM) are less likely to leave the firm. A priori we could expect a similar effect for overtime workers because the performance of overtime work indicates that the enterprise has a strong demand for these employees. The coefficient of eOT shows the opposite, the relation is positive. In this context we should take into account that the workforce can be substituted partially by overtime work. The incorporation of a one-year lagged variable demonstrates that internal adjustment prior to the separation decision has reverse effects. If no further promotions follow we observe a tendency to quit the job, whereas working overtime in the past does not favour external mobility. These results also hold under neglecting instantaneous effects - not in the Tables. Finally, we should stress that lagged influences cannot be detected in panel estimates. They are completely insignificant.

It is noticeable that individual characteristics such as SEX, KIDS and SCHOOL have no clear effects on external mobility. Nevertheless the signs of the coefficients of KIDS and SCHOOL are in accordance with our expectations. Educated workers and workers without children are more mobile. TENURE has the expected sign if this variable measures the specific human capital (SHC), the influence is insignificant, however. An interpretation is that SHC does not increase continuously with tenure. Capital will become obsolete. Thus, mediumterm tenure is probably a better indicator of SHC than entire tenure. Therefore, we use the total employee-months in the firm within the period 1999-2005 (TEN9905) as an alternative measure of SHC. If we substitute TENURE in Table 4 by TEN9905, we find a negative and highly significant influence (not in the Tables).

As internal mobility exhibits a falling trend, an increase of external mobility could compensate this development. However, this trend is also negative. This means all in all that the firm is characterised by a decreasing labour mobility. In contrast to internal mobility the estimates demonstrate a cyclical course of external job changes. Higher unemployment rates (UR) reduce the probability to separate from the firm. A problem with the results of Table 4 is that it does not distinguish between reasons for external job changes. Other investigations have impressively demonstrated that the factors influencing quits and layoffs are very different (Campbell 1997, Giuliano/Levine/Leonard 2006).

In Table 5 multinomial probit estimates for four reasons of separating from the firm are presented in two versions, with and without lagged variables. The conventional distinction is between quits and layoffs. Additionally, we distinguish between cancellation agreements and entries into a transfer organisation. The results display fundamental differences and also some similarities. We find a negative trend (YEAR), a cyclical behaviour (UR) and a positive correlation 
between wages and separation for all four reasons. The internal mobility (ePROM, eOT) has significant instantaneous impacts on the layoff risk and the risk to pass into the transfer organisation while lagged influences are effective in all four cases. The former two causes of separation are comparable as in both cases the decision is more strongly determined by the employer, whereas employees will finally make the decision to quit or to accept a cancellation agreement. As our empirical analysis focuses on individual level, we can only implicitly argue that our firm pursue a different adjustment strategy for different groups of workers.

An increasing probability of overtime work leads instantaneously to a higher risk of a layoff or a switch into the transfer organisation. Although this result is mitigated by positive lagged effects we have to ask what's the logic behind this result? Excess work is an indicator that the firm has a strong demand for these employees. However, in a crisis with a falling product demand the firm has to save costs. Dismissals are one way to reduce costs. The required cost reduction is more easily attained if workers with overtime are laid-off than employees with standard working hours. In other words, fewer workers have to be dismissed in the former than in the latter case to achieve a constant level of cost reductions. This is beneficial for the firm as less negative reactions of the remaining work force are expected, and it is cheaper to expand the working hours than to hire new employees if product demand is rising again.

Furthermore, firms want to keep their promoted employees. They have invested in them and they have tested that their abilities are valuable for the enterprise. The quit decision depending on promotion is ambiguous. On the one hand an individual might expect a further rise within the hierarchy. On the other hand another promotion could be impossible because the hierarchy is too flat and therefore the individual quits. Empirics support the latter hypothesis though the relation is only significant for delayed effects.

All in all, the multinomial approach is more successful in explaining the separations that are primarily determined by the firm than the separations initiated by decisions of individual workers. Individual characteristics such as SCHOOL, SEX and KIDS are not very important, although we should emphasize that females are more willing to accept a cancellation agreement than males. The effect of TEN9905 is negative and highly significant for all four separation reasons. If the entire tenure variable (TENURE) is used only a vague impact is detected (the results are not presented in the Tables). Long tenure reduces only the quit decision significantly.

\section{Summary}

This paper investigates internal and external labour mobility of employees. Personnel records from one company are used for the period 1999 to 2005. This has the advantage that it is not necessary to control for firm specific characteristics. The most notable results are:

(i) Promotion and overtime work are negatively correlated via jointly unobserved variables. 
(ii) Internal labour mobility has an impact on external mobility. Promoted employees and employees without overtime work are less likely to separate from the firm.

(iii) Our approach is more successful in explaining separations that are primarily determined by the firm than separations based on decisions by individual employees.

(iv) There is a tendency of reduced internal as well as external mobility, whereas pro-cyclical effects can only be observed for external employment adjustments. Apparently, management concentrates on dismissals in a specific period.

(v) Due to the last result, given the conditions of employment protection in Germany, transfer organisations providing counselling, supporting job search and offering further training are a policy instrument that helps companies to implement and concentrate layoffs. Apart from enhancing labour market flexibility transfer organisations play an important role in the process of clustering downsizing. 


\section{References}

Baker, G., B. Holmstrom (1995), Internal Labor Markets: Too Many Theories, Too Few Facts. American Economic Review 85: 255-259.

Bewley, T. (2005), Fairness, Reciprocity and Wage Rigidity, in: H. Gintis et al. (Eds.), Moral Sentiments and Material Interests - The Foundations of Cooperation in Economic Life. Cambridge/London: 303-338.

Cahuc, P., A. Zylberberg (2001), Labor Economics, Cambridge/London.

Cahuc, P., A. Zylberberg (2006), The Natural Survival of Work - Job Creation and Job Destruction in a Growing Economy, Cambridge/London.

Campbell, C.M. (1997), The Determinants of Dismissals, Quits and Layoffs: A Multinomial Logit Approach. Southern Economic Journal 63: 1066-1073.

Cappelli, P., D. Neumark (2004), External Churning and Internal Flexibility: Evidence on the Functional Flexibility and Core-Periphery Hypotheses. Industrial Relations 43: 148-182.

Cornelißen, T., O. Hübler (2008), Downward wage rigidity and job mobility. Empirical Economics 34: 205-230.

Doeringer, P., M. Piore (1971), Internal Labor Markets and Manpower Analysis, New York.

Franz, W., F. Pfeiffer (2003), Zur ökonomischen Rationalität von Lohnrigiditäten aus der Sicht von Unternehmen. Jahrbücher für Nationalökonomie und Statistik 223: 23-57.

Gerlach, K., C. Pfeifer (2006), Betriebsinterne Arbeitsmärkte im Licht neuerer theoretischer und empirischer Analysen, in: W. Brandes, T. Eger, M. Kraft (Eds.), Wirtschaftswissenschaften zwischen Markt, Norm und Moral. Kassel: 291-316.

Gibbs, M., W. Hendricks (2004), Do Formal Salary Systems Really Matter? Industrial and Labor Relations Review 58: 71-93.

Giuliano, L., D. Levine, J. Leonard (2006), Do Race, Age, and Gender Differences Affect Manager-Employee Relations? An Analysis of Quits, Dismissals, and Promotions at a Large Retail Firm, Institute for Research on Labor and Employment, Working Paper.

Grund, C. (2002), Empirische Analysen auf Basis betrieblicher Personaldaten. WiSt 31: 627-632.

Hübler, O. (2005), Sind betriebliche Bündnisse für Arbeit erfolgreich? Jahrbücher für Nationalökonomie und Statistik 225: 630-652.

Hübler, O. (2006), Zum Einfluss betrieblicher Bündnisse auf die wirtschaftliche Lage der Unternehmen. Jahrbuch für Wirtschaftswissenschaften 57: 121-146. 
Knoppik, C., T. Beissinger (2003), How rigid are nominal wages? Evidence and implications for Germany. Scandinavian Journal of Economics 105: 643-659.

Lin, M-J. (2005), Opening the Black Box: The Internal Labor Market of Company X. Industrial Relations 44: 659-706.

Newey, W.K. (1999), Consistency of two-step sample selection estimator despite misspecification of distribution. Economics Letters 63: 129-132.

Olsen, R.J. (1980), A Least Squares Correction for Selectivity Bias. Econometrica 48: $1815-1820$.

Paprotny, R. (2008), Transfergesellschaften: Ein sinnvolles Instrument? Ergebnisse einer qualitativen Studie. Hannover.

Pfeifer, C. (2008), Determinants of Promotions in an Internal Labour Market: Testing Implications from Tournament Theory and Efficient Allocation of Workers, Hannover, unpublished manuscript.

Schlicht, E. (1998), On Custom in the Economy, Oxford. 
Table 1: Variable definitions, number of observations, mean and standard deviation measured in employee-months of 1999-2005

Variable - Definition

AGE - age in years

EJM - dummy=1, if external job mobility

eOT - estimated overtime (see eq. (1))

ePROM - estimated PROM (see eq. (1))

GRANTS - supplementary grants per year

KIDS - number of children

OT - dummy $=1$, if overtime working

PROM - dummy $=1$, if promotion last period

REASON to leave the firm - catecorial variable (0-stayer, 1-quit, 2-layoff, 3-cancel-

lation agreement, 4-transfer organisation)

SEX - dummy $=1$, if female

$\mathrm{SCHOOL}$ - dummy $=1$, if high school

(Abitur) or university degree

TARGET - dummy=1, if target agreement

TENURE - number of years within the firm

TEN9905 - tenure in months in 1999-2005

TRAIN - dummy=1, if occupational

training

VCOMP - dummy $=1$, if variable

compensation

UR - unemployment rate in the region

(Bundesland) of the firm (in \%)

WAGE - monthly gross wage

WC - dummy $=1$, if white collar worker

In a high position

WHOURS - standard working hours per month
N

Mean Std.dev.

$\begin{array}{rrr}123896 & 42.2023 & 9.1217 \\ 123896 & 0.0041 & 0.0615 \\ 105589 & -1.6662 & 1.2646 \\ 105589 & -2.6875 & 0.4253 \\ 121425 & 4866.4020 & 4223.6010 \\ 123896 & 0.7055 & 0.9133 \\ 123896 & 0.0849 & 0.2787 \\ 123896 & 0.0051 & 0.0711 \\ 8567 & 5.4429 & 3.0274\end{array}$

$\begin{array}{lll}123896 & 0.2402 & 0.4272 \\ 123896 & 0.3101 & 0.4626\end{array}$

$\begin{array}{lll}107928 & 0.0847 & 0.2784\end{array}$

$123896 \quad 14.3271 \quad 9.4439$

$123896 \quad 74.3377 \quad 16.6804$

$\begin{array}{lll}123896 & 0.6513 & 0.4766\end{array}$

$123896 \quad 84.9430 \quad 163.7649$

$\begin{array}{lll}123896 & 10.9770 & 0.9806\end{array}$

$123896 \quad 3052.1800 \quad 1249.6880$

$\begin{array}{lll}123896 & 0.0871 & 0.2821\end{array}$

$123896 \quad 151.2733 \quad 15.5982$ 
Table 2a: Mobility and earnings indicators measured in December 1999-2005

\begin{tabular}{|c|c|c|c|c|c|c|c|}
\hline & \multicolumn{7}{|c|}{ Mean and standard deviation in parentheses } \\
\hline & 1999 & 2000 & 2001 & 2002 & 2003 & 2004 & 2005 \\
\hline EJM & $\begin{array}{c}0.0051 \\
(0.0715)\end{array}$ & $\begin{array}{c}0.0035 \\
(0.0588)\end{array}$ & $\begin{array}{c}0.0077 \\
(0.0873)\end{array}$ & $\begin{array}{c}0.0050 \\
(0.0706)\end{array}$ & $\begin{array}{c}0.0053 \\
(0.0727)\end{array}$ & $\begin{array}{c}0.0027 \\
(0.0517)\end{array}$ & $\begin{array}{c}0.0036 \\
(0.0596)\end{array}$ \\
\hline PROM & $\begin{array}{c}0.0198 \\
(0.1393)\end{array}$ & $\begin{array}{c}0.0194 \\
(0.1380)\end{array}$ & $\begin{array}{c}0.0205 \\
(0.1417)\end{array}$ & $\begin{array}{c}0.0231 \\
(0.1504)\end{array}$ & $\begin{array}{c}0.0106 \\
(0.1025)\end{array}$ & $\begin{array}{c}0.0040 \\
(0.0633)\end{array}$ & $\begin{array}{c}0.0000 \\
(0.0000)\end{array}$ \\
\hline OT & $\begin{array}{c}0.0777 \\
(0.2677)\end{array}$ & $\begin{array}{c}0.1353 \\
(0.3422)\end{array}$ & $\begin{array}{c}0.1108 \\
(0.3139)\end{array}$ & $\begin{array}{c}0.1463 \\
(0.3536)\end{array}$ & $\begin{array}{c}0.0571 \\
(0.2320)\end{array}$ & $\begin{array}{c}0.0563 \\
(0.2306)\end{array}$ & $\begin{array}{c}0.0571 \\
(0.2320)\end{array}$ \\
\hline TENURE & $\begin{array}{l}14.2088 \\
(8.7151)\end{array}$ & $\begin{array}{l}14.1587 \\
(9.1227)\end{array}$ & $\begin{array}{l}13.7306 \\
(9.5858)\end{array}$ & $\begin{array}{l}14.0244 \\
(9.7373)\end{array}$ & $\begin{array}{l}14.6371 \\
(9.7066)\end{array}$ & $\begin{array}{l}14.7738 \\
(9.8522)\end{array}$ & $\begin{array}{l}15.4967 \\
(9.8191)\end{array}$ \\
\hline WAGE & $\begin{array}{c}2840.65 \\
(1120.87)\end{array}$ & $\begin{array}{c}2925.58 \\
(1194.02)\end{array}$ & $\begin{array}{c}3007.14 \\
(1266.29)\end{array}$ & $\begin{array}{c}2999.19 \\
(1140.06)\end{array}$ & $\begin{array}{c}3095.71 \\
(1249.20)\end{array}$ & $\begin{array}{c}3220.13 \\
(1289.50)\end{array}$ & $\begin{array}{r}3305.55 \\
(1370.47)\end{array}$ \\
\hline GRANTS & $\begin{array}{c}4426.73 \\
(3516.22)\end{array}$ & $\begin{array}{c}4333.36 \\
(3493.97)\end{array}$ & $\begin{array}{c}4483.07 \\
(4296.93)\end{array}$ & $\begin{array}{c}4618.61 \\
(3186.75)\end{array}$ & $\begin{array}{c}4773.73 \\
(3937.18)\end{array}$ & $\begin{array}{c}5201.97 \\
(4461.75)\end{array}$ & $\begin{array}{r}5714.36 \\
(5983.36)\end{array}$ \\
\hline $\mathrm{n}$ & 1365 & 1441 & 1562 & 1599 & 1507 & 1492 & 1402 \\
\hline
\end{tabular}

Note: Variable definitions see Table 1; $\mathrm{n}$ - number of employees.

Table 2b: Reasons of separation (1999-2005)

\begin{tabular}{lccccccc} 
Reason of separation & 1999 & 2000 & 2001 & 2002 & 2003 & 2004 & 2005 \\
\hline QUIT & 8 & & 5 & 7 & 16 & 7 & 10 \\
LAYOFF & 2 & 1 & & 2 & 2 & 5 & 2 \\
CANCELLATION AGREEMENT & 2 & & 3 & 8 & 5 & 9 \\
TRANSFER ORGANISATION & & & & & 66 & 3 & \\
END of FIXED-TERM CONTRACT & & 1 & 2 & 3 & 11 & 10 & 17 \\
INTERNAL JOB CHANGE & & & & & & 2 & 77 \\
DISMISSAL without NOTICE & & & & & 1 & & 1 \\
RETIREMENT & & 1 & & 2 & 9 & 4 & 10 \\
DEATH & 10 & 4 & 7 & 19 & 114 & 38 & 127 \\
\hline Total & & & & & & & 1 \\
\end{tabular}


Table 2c: Descriptive statistics 2003

$$
\mathrm{AGE}<=30 \quad \text { AGE }>=50
$$

\begin{tabular}{lcccccc} 
Variable & $\mathrm{N}$ & Mean & Std. Dev. & $\mathrm{N}$ & Mean & Std. Dev. \\
\hline EJM & 2380 & 0.0088 & 0.0935 & 4843 & 0.0112 & 0.1050 \\
PROM & 2380 & 0.0055 & 0.0737 & 4843 & 0.0012 & 0.0352 \\
OT & 2380 & 0.0408 & 0.1978 & 4843 & 0.0493 & 0.2166 \\
TENURE & 2380 & 4.0285 & 2.4830 & 4843 & 22.753 & 9.2276
\end{tabular}

SEX $=1 \quad$ SEX $=0$

\begin{tabular}{lcccccc} 
Variable & $\mathrm{N}$ & Mean & Std. Dev. & $\mathrm{N}$ & Mean & Std. Dev. \\
\hline EJM & 4547 & 0.0090 & 0.0945 & 14269 & 0.0056 & 0.0747 \\
PROM & 4547 & 0.0035 & 0.0592 & 14269 & 0.0032 & 0.0567 \\
OT & 4547 & 0.0172 & 0.1299 & 14269 & 0.0644 & 0.2455 \\
TENURE & 4547 & 13.021 & 9.1501 & 14269 & 14.740 & 9.8863
\end{tabular}

$\mathrm{SCHOOL}=1 \quad \mathrm{SCHOOL}=0$

\begin{tabular}{lcccccc} 
Variable & $\mathrm{N}$ & Mean & Std. Dev. & $\mathrm{N}$ & Mean & Std. Dev. \\
\hline EJM & 5867 & 0.0085 & 0.0919 & 12949 & 0.0055 & 0.0738 \\
PROM & 5867 & 0.0041 & 0.0638 & 12949 & 0.0029 & 0.0541 \\
OT & 5867 & 0.0249 & 0.1558 & 12949 & 0.0657 & 0.2478 \\
TENURE & 5867 & 10.461 & 8.3898 & 12949 & 16.075 & 9.8065
\end{tabular}

Note: Variable definitions see Table 1. 
Table 3: Bivariate ML probit estimates of promotion and overtime

\begin{tabular}{|c|c|c|c|c|}
\hline & & Robust & & \\
\hline & Coef. & Std. Err. & z & $P>|z|$ \\
\hline$\overline{\text { PROM }}$ & & & & \\
\hline GRANTS $/ 10^{3}$ & -0.0079 & 0.0074 & -1.07 & 0.285 \\
\hline VCOMP $/ 10^{3}$ & 0.0293 & 0.1107 & -0.26 & 0.792 \\
\hline TARGET & 0.3097 & 0.2163 & -1.43 & 0.152 \\
\hline WAGE & 0.0008 & 0.0001 & 7.07 & 0.000 \\
\hline WAGE $^{2} / 10^{4}$ & -0.0945 & 0.0156 & -6.07 & 0.000 \\
\hline AGE & 0.0103 & 0.0135 & 0.77 & 0.444 \\
\hline $\mathrm{AGE}^{2}$ & -0.0004 & 0.0002 & -2.29 & 0.022 \\
\hline SCHOOL & -0.0061 & 0.0434 & -0.14 & 0.888 \\
\hline WC & 0.5284 & 0.2159 & 2.45 & 0.014 \\
\hline TRAIN & -0.0262 & 0.0379 & -0.69 & 0.490 \\
\hline WHOURS & -0.0003 & 0.0017 & -0.16 & 0.873 \\
\hline UR & -0.0333 & 0.0234 & -1.42 & 0.155 \\
\hline YEAR & -0.0978 & 0.0110 & -8.89 & 0.000 \\
\hline Constant & 192.6902 & 21.9709 & 8.77 & 0.000 \\
\hline OT & & & & \\
\hline GRANTS $/ 10^{3}$ & -0.0516 & 0.0109 & -4.73 & 0.000 \\
\hline VCOMP $/ 10^{3}$ & 1.0838 & 0.1183 & 9.16 & 0.000 \\
\hline TARGET & 0.5572 & 0.3029 & 1.84 & 0.066 \\
\hline WAGE & 0.0018 & 0.0002 & 8.39 & 0.000 \\
\hline WAGE$^{2 / 1} / 0^{4}$ & -0.0024 & 0.0003 & -7.30 & 0.000 \\
\hline AGE & 0.0103 & 0.0193 & 0.54 & 0.592 \\
\hline $\mathrm{AGE}^{2}$ & -0.0001 & 0.0002 & -0.58 & 0.559 \\
\hline SCHOOL & -0.4372 & 0.0834 & -5.24 & 0.000 \\
\hline WC & -1.5066 & 0.3280 & -4.59 & 0.000 \\
\hline TRAIN & -0.1718 & 0.0639 & -2.69 & 0.007 \\
\hline WHOURS & 0.0127 & 0.0031 & 4.16 & 0.000 \\
\hline UR & 0.0145 & 0.0134 & 1.08 & 0.280 \\
\hline YEAR & -0.1016 & 0.0094 & -10.80 & 0.000 \\
\hline Constant & 197.1183 & 18.8229 & 10.47 & 0.000 \\
\hline $\mathrm{N}$ & & 105589 & & \\
\hline Wald test & $\mathrm{CHI}^{2}(26)$ & 694.21 & Prob value & 0.0000 \\
\hline rho & & -0.0862 & & \\
\hline Test of $r h o=0$ & $\mathrm{CHI}^{2}(1)$ & 8.465 & Prob value & 0.0036 \\
\hline
\end{tabular}

Note: Variable definitions see Table 1. 
Table 4: ML probit estimates of external job mobility

\begin{tabular}{|c|c|c|c|c|c|c|c|c|}
\hline & \multicolumn{2}{|c|}{ Probit ML } & \multicolumn{2}{|c|}{ Probit ML } & \multicolumn{2}{|c|}{ RE Probit ML } & \multicolumn{2}{|c|}{ RE Probit ML } \\
\hline & Coef. & $\begin{array}{l}\text { Robust } \\
\text { Std.Err. }\end{array}$ & Coef. & $\begin{array}{l}\text { Robust } \\
\text { Std.Err. }\end{array}$ & Coef. & Std.Err. & Coef. & Std.Err \\
\hline ePROM & -0.6043 & 0.2634 & -1.3114 & 0.2645 & -0.8828 & 0.4534 & -0.9932 & 0.5503 \\
\hline eOT & 0.2226 & 0.1028 & 0.3918 & 0.1016 & 0.3484 & 0.1902 & 0.3342 & 0.2198 \\
\hline ePROM(L12) & & & 1.0443 & 0.0790 & & & 0.4636 & 0.3382 \\
\hline eOT(L12) & & & -0.2487 & 0.0305 & & & -0.0866 & 0.1110 \\
\hline GRANTS/103 & -0.0019 & 0.0141 & 0.0009 & 0.0145 & 0.0356 & 0.0167 & 0.0342 & 0.0174 \\
\hline VCOMP & 0.1683 & 0.2379 & 0.1750 & 0.2365 & 0.1883 & 0.4693 & 0.2381 & 0.6151 \\
\hline WAGE/10 3 & 0.1963 & 0.0749 & 0.1740 & 0.0767 & 0.1165 & 0.1414 & 0.0340 & 0.1480 \\
\hline TENURE & -0.0088 & 0.0059 & -0.0085 & 0.0060 & -0.0110 & 0.0116 & -0.0056 & 0.0121 \\
\hline WHOURS & -0.0076 & 0.0039 & -0.0071 & 0.0039 & -0.0118 & 0.0070 & -0.0070 & 0.0071 \\
\hline SCHOOL & 0.1822 & 0.1415 & 0.1216 & 0.1430 & 0.5106 & 0.2381 & 0.4713 & 0.2521 \\
\hline SEX & 0.2119 & 0.1133 & 0.1647 & 0.1121 & 0.2409 & 0.2160 & 0.3124 & 0.2178 \\
\hline KIDS & -0.0986 & 0.0565 & -0.0946 & 0.0567 & -0.0872 & 0.1040 & -0.0850 & 0.1076 \\
\hline UR & -0.5688 & 0.0508 & -0.5691 & 0.0524 & 0.0378 & 0.0966 & 0.0310 & 0.0997 \\
\hline YEAR & -0.3632 & 0.0313 & -0.4007 & 0.0328 & -0.1921 & 0.0602 & -0.2016 & 0.0632 \\
\hline Constant & '730.58 & 62.757 & 806.38 & 65.664 & 373.52 & 120.02 & 392.63 & 126.10 \\
\hline
\end{tabular}

Note: L12 - Lag of 12 months; other variable definitions see Table 1. 
Table 5: Multinomial ML probit estimates of external job mobility with respect to reason of separation

Robust Robust

Coef.Std.Err. Coef.Std.Err.

\section{QUIT}

ePROM

$0.7571 \quad 0.4909-0.13420 .5028$

eOT

ePROM(L12)

$\begin{array}{llll}-0.0879 & 0.1813 & 0.1848 & 0.1779\end{array}$

eOT(L12)

$\begin{array}{lll}1.4841 & 0.2152\end{array}$

GRANTS $/ 10^{3}$

$-0.41170 .0593$

VCOMP

WAGE

TEN9905

WHOURS

SCHOOL

SEX

KIDS

UR

YEAR

Constant

$\begin{array}{lllll}0.0367 & 0.0215 & 0.0491 & 0.0214\end{array}$

$\begin{array}{lllll}-0.1270 & 0.5534 & -0.1569 & 0.5735\end{array}$

$\begin{array}{lllll}0.0002 & 0.0002 & 0.1338 & 0.2118\end{array}$

$\begin{array}{lllll}-0.0548 & 0.0046 & -0.0583 & 0.0049\end{array}$

$\begin{array}{llll}-0.0034 & 0.0121 & -0.0021 & 0.0123\end{array}$

$\begin{array}{lllll}0.0092 & 0.3167 & -0.1343 & 0.3381\end{array}$

$\begin{array}{lllll}0.4698 & 0.2810 & 0.4089 & 0.2798\end{array}$

$\begin{array}{lllll}-0.0204 & 0.1906 & -0.0127 & 0.1971\end{array}$

$\begin{array}{llll}-0.7691 & 0.1280 & -0.7772 & 0.1237\end{array}$

$\begin{array}{lllll}-0.4029 & 0.0734 & -0.4673 & 0.0783\end{array}$

$\begin{array}{lllll}816.38 & 147.15 & 946.76 & 156.85\end{array}$

\section{LAYOFF}

ePROM

$\begin{array}{llll}-1.6488 & 0.7719 & -2.4384 & 0.7594\end{array}$

eOT

ePROM(L12)

$\begin{array}{lllll}0.7780 & 0.3535 & 0.9988 & 0.3525\end{array}$

0.94980 .2336

eOT(L12)

$-0.21160 .0709$

GRANTS $/ 10^{3}$

$\begin{array}{lllll}0.0560 & 0.0233 & 0.0624 & 0.0265\end{array}$

VCOMP

WAGE

TEN9905

WHOURS

SCHOOL

SEX

KIDS

UR

YEAR

Constant

$\begin{array}{llll}-0.9654 & 0.9692 & -1.3611 & 1.1535\end{array}$

$\begin{array}{lllll}0.0006 & 0.0003 & 0.6358 & 0.2696\end{array}$

$\begin{array}{llll}-0.0479 & 0.0050 & -0.0487 & 0.0052\end{array}$

$\begin{array}{llll}-0.0396 & 0.0139 & -0.0412 & 0.0146\end{array}$

$\begin{array}{lllll}0.4745 & 0.4783 & 0.4706 & 0.4845\end{array}$

$\begin{array}{lllll}0.3457 & 0.5577 & 0.3269 & 0.5762\end{array}$

$\begin{array}{lllll}0.2790 & 0.1440 & 0.2606 & 0.1418\end{array}$

$\begin{array}{lllll}-0.7028 & 0.1008 & -0.6456 & 0.0972\end{array}$

$\begin{array}{llll}-0.4804 & 0.0658 & -0.5238 & 0.0631\end{array}$

968.77131 .891055 .71126 .45 
